\title{
PDGFRA Gene
}

National Cancer Institute

\section{Source}

National Cancer Institute. PDGFRA Gene. NCI Thesaurus. Code C24666.

This gene plays a role in mitogenic activities affecting mesenchymal cells and is involved

in receptor tyrosine kinase signal transduction. 